\title{
Role of Email in Intercultural Communication of Criticism in a Chinese English Curriculum Reform Context
}

\author{
Linqiong L $\ddot{u}^{1}$ \\ ${ }^{1}$ School of English and Education, Guangdong University of Foreign Studies \\ Correspondence: Linqiong Lü, School of English and Education, Guangdong University of Foreign Studies, \\ Guangzhou, Guangdong, China. E-mail: lingqionglv@gdufs.edu.cn
}

Received: October 19, 2017 Accepted: January 23, 2018 Online Published: January 25, 2018

doi: 10.5539/elt.v11n2p193 URL: http://doi.org/10.5539/elt.v11n2p193

\begin{abstract}
Western teachers working in China often experience cultural conflicts arising from, for instance, the ways that Chinese students perceive face and express criticism. To better understand these face-concerned conflicts, this paper explores the role and significance of email for a group of Chinese students to communicate pedagogical criticism with their western teacher as part of an undergraduate program in Communicative Language Teaching (CLT). A quantitative and qualitative examination of the politeness strategies employed by the Chinese students in their critical emails revealed the three roles of email: email as a safe, polite and effective channel for the Chinese students to express critical views directly (without turning to a third party) and collectively (on behalf of the other students), email as a major means for their western teacher to be informed about problems privately, and email as a springboard for the western teacher to communicate later with more other students publicly. What was criticized in the emails indicated the fundamental disparities in their perceptions of knowledge, the identity of English, and the classroom behavior of silence. Interpretation and discussion of findings were informed by the studies of Chinese psychology and the writer's insider knowledge gained from her four-year longitudinal participant observation.
\end{abstract}

Keywords: English language teaching, face, politeness strategy, computer-mediated communication, curriculum reform, intercultural communication

\section{Introduction}

Since the early 1980s, CLT approach has been vigorously promoted and implemented in China's English language teaching. However, many studies reported difficulties due to the disparate philosophical underpinnings of CLT and China's traditional teaching methods (see comprehensive reviews in Dzau, 1990; Cortazzi \& Jin, 1996; Simpson, 2008; Tsui, 2007). CLT belongs to a liberalist pedagogy rooted in individualism and egalitarianism, a western philosophy in conflict with China's Confucian conservatism (Hayhoe, 1996; Lo, 1984; Ouyang, 2004). The conflictual beliefs and values lead to misinterpretations among Chinese students and their western teachers. One of these misinterpretations arises from the way Chinese students express skepticism, complaints, disagreement, or, as a matter of fact, criticism. Since in Chinese culture, a more vertical hierarchy exists and harmony is highlighted in interpersonal relationship (Gao, Ting-Toomey \& Gudykunst, 1996; Hofestede, 2008; Hu \& Grove, 1991), Chinese students often use indirect means such as "the third party" to voice their complaints. Western teachers cultivated in a Utilitarian discourse system where information should be conveyed with clarity, brevity and sincerity, may take for granted that the ways to resolve disputes between two parties should be something like truth seeking (R. Scollon \& S. Scollon, 1995). Consequently, the avoidance of confronting directly the face of their teacher seniors is intended by Chinese students as a gesture to show their respect but, on the contrary, may often be misunderstood by their western teachers as backstabbing or secretive manipulation (Oatey, 1990; Ouyang 2004).

With the increasing use of computer-mediated communication (CMC), there is a growing body of literature on how to integrate email and other forms of online communication into language teaching and learning (e.g. Barson, Frommer, \& Schwartz, 1993; Hu, Cheah, \& Wong, 2009; Lewis, Treves, \& Shaindlin, 1997; Vinagre, 2008; Yu \& Zeng, 2011). However, most studies are task-based, focusing on cost, efficiency, and productivity. They overlook the social interaction aspect of email communication and ignore the changes that communication technology may effect upon social relations (Cutler, 1996; Vinagre, 2008). As one form of CMC, email is a 
creolization of oral and written discourse (Alharbi, 2015; Lightfoot, 2006). Compared with face-to-face communication, email breaks the limits of time and space and has the potential for extending traditional social interactions (Bloch, 2002, p. 119). The absence of social presence in email communication provides anonymity and privacy (Lewis, Treves, \& Shaindlin, 1997). Email can thus provide the email writers the freedom of assuming another persona (Turkle, 1995), creating impressions differing from those formed via the face-to-face mode (Okdie, Guadagno, Bernieri, Geers, \& Mclarney-Vesotski, 2011). Email, similar to other means of online communication, has become an ideal tool for building and maintaining social relations (Baron, 1998; Lewandowski, Rosenberg, Parks, \& Siegel, 2011). In this paper, the author focuses on the social effects that email communication of criticism exerted on intercultural teacher-student relations in an English curriculum reform context of mainland China.

Since criticism is a face-threatening act which may make another person feel uneasy and defensive, politeness strategies are often used to mitigate threat and protect each others' face. The study adopted Brown and Levison's (1978/1987) theory on face and politeness as the main explanatory framework for interpreting Chinese students' tactics to communicate criticism. Three research questions were explored: What was the criticism about? What linguistic and rhetoric politeness strategies did the students use? On whose behalf was the criticism expressed? Both qualitative and quantitative methods were used in collecting and analyzing data.

\section{Face and Politeness}

\subsection{Two Kinds of "Face": Positive and Negative}

Drawing on Goffman's (1967) work on "face", Brown and Levinson (1978/1987) define face as the public self-image that every member wants to claim for himself and argue that the image of face consists of two sides which are two conflicting face wants: positive face is a face want of being liked by others and negative face is a face desire of acting unimpededly by others. To secure the face image, conversational participants have to perform "facework". Acts which are intrinsically fact-threatening have to be readdressed by using politeness strategies.

\subsection{The Differences between the Western and Chinese "Face"}

There are differences in western and Chinese concepts of face. Western face can be deemed as individualistic, self-oriented image, while Chinese face is communal and interpersonal (Zhang, 1995). It is obvious that "face" in Brown and Levinson's work centers around the individual aspect of face, i.e., face of an image that intrinsically belongs to the "self"; this self-image primarily concerns the individual's desires and becomes public on the premises that the others' face is maintained (Yu, 2003). Differently, in Chinese culture, face is more public, other-centered and interactional. $\mathrm{Hu}$ (1944; cf. Yu, 2003) has argued that in Chinese culture there are two kinds of "face": "mianzi" and "lian". "Mianzi" refers to prestige or reputation either achieved through getting on in life or, ascribedly, other members of one's own community. "Lian" refers to the respect of the group for a man with a good moral standard and, therefore, indicates the confidence of society in the integrity of one's moral character. Both "mianzi" and "lian" revolve around a recognition by others and one's desire for social prestige, reputation or sanction. Viewed in this light, Chinese facework involves "an interactional orientation on the part of the individual speaker toward establishing connectedness to, and seeking interpersonal harmony with, one's own community" (Mao, 1994, p. 459). It is the harmony of individual behavior with the judgment of the community, rather than the accommodation of the individual desired, that Chinese face emphasizes (Yu, 1997, 1999, 2003). The kind of face a Chinese gets is better to be regarded as a public image which depends on and is determined by the participation of others (Mao, 1994).

\subsection{Politeness Strategies}

\subsubsection{Linguistic Politeness Strategies}

However, as far as the goals of politeness facework are concerned, i.e., to maintain and even enhance face during conversations, the differences between Chinese and western conceptions are not that radical (Yu, 2003, p. 1685) and can be accommodated in Brown and Levinson's (1978/1987) model of politeness. Compared with other models of politeness, Brown and Levinson's model is the one that most clearly maintains its pancultural validity, thus evidently claiming its application as a basis for intercultural comparison (O'Driscoll, 1996). Brown and Levinson have outlined five main politeness strategies. The first is bald-on-record, i.e., to do the face-threatening-act (FTA) directly without any redressive action (Note 1). The second is positive politeness, i.e., to perform an FTA with redressive action which attends to the hearer's positive face. The third is negative politeness, i.e., to do the FTA with the redressive action that satisfies the addressee's negative face. The fourth is go-off-record, i.e., to use ambiguous language, such as irony, rhetorical questions, being vague, etc. The last is to 
avoid FTAs by not doing them at all.

According to Grice's (1978) Cooperative Principle and Brown and Levinson's Manner Principle, marked use of personal pronouns can generate pragmatic effects. The switching of the speaker's personal pronouns, though, may blur his/her identity, can achieve politeness by requiring the hearer to adjust his/her position of viewing and thus change the mental distance between the topic and the illocutionary participants, especially when the topic is unpleasant (N. Zhang, 2005).

\subsubsection{Rhetoric Politeness Strategies}

Besides the linguistic politeness strategies, R. Scollon and S. Scollon (1995) have added another category of politeness strategy by including the use of deductive style as a rhetorical positive strategy and the employment of inductive style as a rhetorical negative strategy. Their considerations are: By being deductive the speaker attempts to include the hearer and presumes that the hearer would totally support and agree with his opinion raised at the beginning; and by being inductive the speaker attempts to give freedom to the hearer and presumes that the hearer may resist his/her position and want to see the facts before opinions. Since the assessment of the seriousness of an FTA is determined by power, social distance and imposition (Brown \& Levinson, 1978/1987), Scollon and Scollon further have argued that the use of positive strategies, which they termed as "involvement strategies", often occurs in two circumstances: One is in a "solidarity politeness system" which sees a symmetrical power and social distance; the other is used by members of higher position in a "hierarchy politeness system" where asymmetrical power and distance exist (pp. 36-47). Therefore, the study of politeness strategies can reveal not only face/politeness tactics, but also the power and social relationship between the interlocutors.

Brown and Levinson's theory and Scollon and Scollon's work offer respectively the linguistic and rhetoric approaches to politeness strategy. The integration of the two approaches in the analysis of the critical emails in this study can therefore provide both linguistically detailed and discursively holistic descriptions of the adopted politeness strategies, paving way for more comprehensive social and cultural interpretations.

\section{Methodology}

\subsection{Context}

The writers of these critical emails are a group of Chinese students enrolled in a four-year innovative pre-service English language education program led by Simon (Note 2), a veteran educator from North America. This program was considered "innovative" by the faculty administrators because of its novel approaches to teacher-student communication and intercultural collaborative teaching. Simon and two Chinese teachers worked together to design and conduct courses including Introduction to Teaching and Creative Learning and Critical Thinking. He used CLT approach and his English class was replete with activities and games. Besides classroom teaching, he created a second outside-class space for teacher-student communication, organizing activities of Simon Tea, Simon Lunch, English Zone and Simon Email Box. This study focuses on the communication activity of Simon Email Box, which was intended by Simon to enhance students' interest in using English for real communication purposes. He encouraged students to write emails to him and promised to reply and continue email conversations.

\subsection{Researcher's Stance}

I was one of the three Chinese teachers who worked closely with Simon to conduct the two courses. My contact with Simon extended the whole four-year program span. I was also the tutor of one class and had spent much time with students inside and outside class. Being both a participant in and an observer of the program over an extensive period, I was, therefore, in a privileged position for obtaining the first-hand data and utilizing my insider knowledge to interpret it.

\subsection{Research Questions}

This study examines the following three research questions:

1) What was the criticism about?

2) What linguistic and rhetoric politeness strategies did the students use?

3) On whose behalf was the criticism expressed?

\subsection{Methods of Data Collection and Analysis}

All the emails were written on students' own initiative. To protect writers' privacy, Simon removed all the names of the email writers before submitting them to the researcher. There were all together 207 student emails along 
with Simon's replies. Triangulation of data was realized by incorporating other kinds of data including the reflective essays that students wrote at the end of each semester, course PPTs, materials and notes, interviews with students, notes taken after talks with Simon and my teaching journals.

A research assistant and I read the data together. We reconciled discrepancies in data reading and I interpreted the results. The data was read and coded in four steps:

First, after reading all the 207 email messages and their replies, we identified 12 emails which expressed criticism in the form of complaints, disapprovals, or critical inquiries. As Simon observed in a recent interview that "face is a big concern for Chinese people" and he had to "learn to be more subtle and indirect", these critical emails were highly interesting in two ways: their writers' directness in approaching the teacher in person to express criticism and the subtleness and indirectness characterizing the critical emails. Since the primary concern of this study is about what and how the criticism is expressed through the communication medium of email, the quantity of these emails is therefore less important. The relative small percentage of the critical emails (about 5\%) shall not impair the importance of this study. The corpus of those 12 emails was then categorized thematically.

Second, we analyzed how directly the criticism was put forward in each email. Those emails which immediately raised their critical points after greetings and/or self introduction were considered as using deductive rhetoric style, and those delaying the introduction of their critical topics were deemed as using inductive rhetoric style.

Third, three kinds of politeness strategies—-bald-on-record, positive, negative and off-record—were identified based upon Brown and Levison's (1978/1987) model of politeness. We gave a code to each politeness strategy identified in these emails: bald-on-record (B), positive strategies $(\mathrm{P}+)$, negative strategies $(\mathrm{P}-)$, and off record (OFF) (Note 3). These strategies sometimes overlapped and a single statement may include more than one strategy. We placed codes directly after the statement where the politeness strategies appeared. We then sorted, recorded and counted all politeness strategies into a table (See Table 2).

Fourth, we underlined and analyzed the marked personal reference pronouns of "we", "you" and "they" which we considered as the realization of "my"/ the writer's voice. Below is one of the critical emails written by a student (Note 4) with codes in brackets:

Dear Lewen, $(\mathrm{P}+4)$

So great to write to you. $(\mathrm{P}+2) \mathrm{I}$ appreciate the way you train us, especially today, probing, questioning. $(\mathrm{P}+2)$ It really makes me think a lot. $(\mathrm{P}+2)$ Actually, for myself, I would like to be taught in this way. $(\mathrm{P}+7)$ I would also like to teach others in this way if I can be a teacher. $(\mathrm{P}+7)$ The traditional way of teaching (based on the textbook), which you called "in the box" makes not only the students but the teacher himself feel boring. $(\mathrm{P}+7)$

However, that is another problem I always think about. (P-2) That is what I said in today's class. You may feel disappointed that in your class the student you train still has such thoughts, but that is real, especially in the places where are not so developed. $(\mathrm{P}+9)(\mathrm{P}+13)$ In these places, the traditional way is the most acceptable one to most people. $(\mathrm{P}+13)$ If the teachers spend more time playing games or some other activities rather than teaching the knowledge in the textbook, they will think you are not doing your job. $(\mathrm{P}+13) \mathrm{We}$ all know learning English is not just to pass the exam (Note 5) but to use it, but for many schools, it is! $(\mathrm{P}+7)(\mathrm{P}-2)$ You said that "you can play game in class", and ask them to do exercise after class, and that is good, but if the students are too lazy to do that, what will be going on ? $(\mathrm{P}+7)(\mathrm{OFF} 10)$

If they don't do, they won't pass the exam. (P+13) If they can't pass the exam, they won't get the chance for further study, and you won't be considered as a good teacher, so you may be under pressure. $(\mathrm{P}+13)$ Even worse, you may get fired. $(\mathrm{P}+13)$ This is the reality in most areas in China today, and it will take a long time to change for it has existed for a very very long time. $(\mathrm{P}+13)$

So, dear Lewen, whenever I think of it, I will feel very confused. $(\mathrm{P}+4)$ If the time when I am a teacher, the situation is still like this, if the students I teach are all in a very low level, even listening to me is difficult for them, are the ways we learn now still useful? (OFF10) Sorry not to see it in the bright way as you wish. (P-6)

Yours,

Linfeng

Simon gave himself a Chinese name Li Lewen. This student began his letter by using Simon's first name in Chinese ("Lewen") to address him and thus gave Simon an in-group identity of being Chinese. By using this in-group identity marker $(\mathrm{P}+4)$, he was trying to break down not only a nationality boundary and add a Chinese flavor to this intercultural dialogue, but also a teacher-student boundary, making this letter appear like the one 
between friends. Before bringing out his critical points, he tried to lower the threat of his criticism by mentioning his interest in and approval $(\mathrm{P}+2)$ of Simon's teaching of probing methods. He continued to seek common ground with Simon $(\mathrm{P}+7)$ by expressing his support and willingness to use Simon's way to teach future students. He placed his critical remarks after a transitional adverbial "however", a hedge marker (P-2) which gave freedom for negotiation by simultaneously carrying two differential opinions and lessened the impact of criticism by somewhat distracting the recipient's attention. He further mitigated the seriousness of the criticizing FTA by showing concerns with Simon's disappointment $(\mathrm{P}+9)$ and continued to give reasons $(\mathrm{P}+13)$ to convince Simon that his skepticism held ground and shall be taken seriously. When talking about the impracticalness of using games, he alleviated the threatening impact by using a collective voice to claim Simon's views on learning English as a commonly recognized fact and thus increased agreement with Simon $(\mathrm{P}+7)$. He surfaced his hedged criticism by using a transitional word "but" (P-2) and employed an off-record politeness strategy of using rhetorical question (OFF10) to show his disapproval. In the last paragraph, he attempted to achieve Simon's understandings of his being critical by offering more reasons $(\mathrm{P}+3)$. By interspersing "dear Lewen" before winding up his letter, he tried to remind Simon that he uttered his different views because he was treating him as a sincere friend $(\mathrm{P}+4)$. Again, he made his criticism mild by using an off-record politeness strategy of using rhetorical question (OFF10). Last, he made an apology (P-6) to show he was sorry to have different opinions and offend Simon's independence face.

\section{Findings and Discussions}

\subsection{What Was the Criticism about?}

Table 1 shows the rhetorical style and content of each critical email. The criticism covers three areas: English teaching and learning approach, course content, and teacher-student relationship. In the following part, I will discuss the conflictual perceptions revealed in the three areas by resorting to my ethnographic knowledge of the program and students.

As to English teaching and learning approach, Simon and his Chinese students held different views. Simon reiterated the significance of KSA (knowledge, skills and attitude) model, viewing knowledge as an integration of knowing, doing and being. He deemed the purpose of learning a language was to use it so that language knowledge could be reinforced and language competence and attitude could be developed. Therefore, he designed assorted courses and activities including games and comic skit acting to create chances for students to use and practice spoken English. However, his Chinese students understood knowledge as something "substantial", structured and testable, preferring textbooks to fun activities. They, the writer of the quoted email in 3.4 for instance, maintained a more realistic approach toward English learning. Though not disagreeing that the purpose of learning a language was for use, they tended to consider it as an ultimate future but not a practical present goal. In order to fulfill the ultimate goal, they had to first achieve an immediate instrumental goal of passing examinations which function more as gatekeepers than assessors of success (Spolsky, 1997; Su, 1998). If they failed in examinations like TEM 4 and TEM 8 (Note 6), they would be denied teaching English in Chinese schools where students were in a similar situation-failure in the national college entrance examination would largely preclude them from pursuing good jobs in multinational workplaces where English was often used. This immediateness may explain why students could not appreciate the value of "too many English activities" which they simply considered as of little immediate relevance to examinations and future work.

Besides the "irrelevant" teaching and learning methods, irrelevancy was also perceived in the course content. For instance, the topics of lingua franca and global English were covered in Simon's classes. Simon wanted his students to regard English as a communicative tool in an international environment where English exhibited multi-ethnicities. He seemed to hold a more global, functional and future-oriented view toward English and gave legitimacy to its local variants. However, his students regarded these topics as having little bearing on improving their English proficiency. They seemed to consider English more as a school subject and pay more attention to its accuracy and particularities which would be tested in examinations. The disparity may explain why students could not understand why Simon denied the importance of phonetic imitation exercises. They were even shocked when Simon said in his lectures that speaking English with a Chinese accent was beautiful. Their surprise was not without a reason. For them they had already taken English exams which not only tested their written but also oral English (Note 7). In the future, most of them would work in local Chinese schools where they would continue to be evaluated by the accuracy of their English grammar and pronunciation. The "accented English" which might not be a problem for westerners like Simon could cause his Chinese students' loss of marks and, in the future, their jobs.

Students' criticism of "too many activities" was actually appreciated by Simon who promised work to together 
with other teachers to coordinate program assignments in the future. As he wrote in reply:

Nothing could be farther from the true intention of the project. I am delighted when my students try to create something completely different from my classroom examples. Nevertheless, the criticism from the students about too many assignments and preparations was valuable input for our program. As teachers, we had not been monitoring very carefully what assignments were being given in other courses and this sometimes produced a lot of work and pressure for our students at certain times of the year. Next year we will coordinate all assignments in the program, so that we can spread the work load more evenly over the term.

Finally, the differing understandings of silence between Simon and his Chinese students may also lead to misunderstandings, criticism and impairment of teacher-student relationship. In Chinese culture, silence is a respectful way for juniors to show their disagreement with their seniors. When it happened in Simon's class, this well-meaning polite gesture of silence could be misinterpreted by him as inactive, as in turn invited his encouragement to activate his students. Afterwards, some of his students overheard the conversation between him and his Chinese colleagues complaining about students' silence and wrote an email to him criticizing his "double faces". Simon wrote back expressing his hope to end the misunderstandings through more public means:

We care about all the (bold in origin) students, and therefore feel it is our duty and responsibility to let you know if we feel you are not working to your potential ... I hope that you — as one of the student leaders - will do your best to end this negative view as quickly as possible. I also urge you to share this message with all of the English education majors.

Table 1. Content analysis of students' critical emails

\begin{tabular}{|c|c|c|c|}
\hline Theme & $\begin{array}{l}\text { Email } \\
\text { entry }\end{array}$ & $\begin{array}{l}\text { Rhetorical } \\
\text { style }\end{array}$ & Critical points \\
\hline \multirow{8}{*}{$\begin{array}{l}\text { English teaching and } \\
\text { learning approach }\end{array}$} & 1 & Deductive & There are too many English classes. \\
\hline & 2 & Deductive & $\begin{array}{l}\text { There are too many English classes and Chinese learning } \\
\text { is ignored. }\end{array}$ \\
\hline & 3 & Deductive & $\begin{array}{l}\text { There are too many English activities and theories; } \\
\text { textbooks are not unnecessary. }\end{array}$ \\
\hline & 4 & Deductive & Imitation is not unnecessary in practicing pronunciation. \\
\hline & 5 & Deductive & Lectures about teaching theories are useless. \\
\hline & 6 & Inductive & $\begin{array}{l}\text { Interrupting students' performance to give comments is } \\
\text { improper. }\end{array}$ \\
\hline & 7 & Inductive & $\begin{array}{l}\text { It is impossible to play games in future teaching in } \\
\text { Chinese middle schools. }\end{array}$ \\
\hline & 8 & Deductive & $\begin{array}{l}\text { The ways of learning vocabulary taught in class are not } \\
\text { useful. }\end{array}$ \\
\hline \multirow[t]{3}{*}{ Course content } & 9 & Inductive & $\begin{array}{l}\text { Logical fallacies taught in class are not likely to be used in } \\
\text { teaching Chinese middle school students. }\end{array}$ \\
\hline & 10 & Deductive & $\begin{array}{l}\text { It is not relevant to talk about lingua franca and global } \\
\text { English in the lectures. }\end{array}$ \\
\hline & 11 & Inductive & $\begin{array}{l}\text { The connection between music and learning English is not } \\
\text { strong and the teacher gave too many requirements of } \\
\text { doing projects, which may put students into the "box". }\end{array}$ \\
\hline $\begin{array}{l}\text { Teacher-student } \\
\text { relationship }\end{array}$ & 12 & Deductive & $\begin{array}{l}\text { It is wrong to dislike students just because they are not } \\
\text { "loud" in class; teachers should not be double-faced, } \\
\text { praising them in front of them and criticizing them behind } \\
\text { their backs; they need to be honest with students. }\end{array}$ \\
\hline
\end{tabular}

In summary, what was criticized in the emails reveals the fundamental disparities in the way the Chinese students and their western teacher view knowledge, the identity of English, and the classroom behavior of 
silence. For the Chinese students, knowledge is substantial, primarily gained from textbooks, and mainly for the purpose of passing exams; English is a school subject and should be learned in an accurate way so as to write and speak like native English speakers; silence is to show respect and if teachers are dissatisfied with it, they should tell them the truth instead of using false praise to encourage them to speak. In contrast, for the western teacher, knowledge is a lively integration of knowing, doing and being, and learning English is for using it; English has become a global communication tool and shall allow local varieties; silence indicates students' low motivation and students should be "warmed up" or energized with encouraging words.

\subsection{What Linguistic and Rhetoric Politeness Strategies Did the Students Use?}

The data was further read and coded according to the different types of politeness strategy. The percentage of each politeness strategy was shown in Table 2.

Table 2. Results of politeness strategies found in students' critical emails

\begin{tabular}{|c|c|c|c|}
\hline Strategy & Number & Percentage & Total percentage of each category \\
\hline $\mathrm{P}+1$ & 4 & 0.9 & \\
\hline $\mathrm{P}+2$ & 18 & 4.2 & \\
\hline $\mathrm{P}+3$ & 2 & 0.5 & \\
\hline $\mathrm{P}+4$ & 16 & 3.8 & \\
\hline $\mathrm{P}+5$ & 1 & 0.2 & \\
\hline $\mathrm{P}+7$ & 29 & 6.8 & \\
\hline $\mathrm{P}+9$ & 5 & 1.2 & \\
\hline $\mathrm{P}+10$ & 6 & 1.4 & \\
\hline $\mathrm{P}+11$ & 5 & 1.2 & \\
\hline $\mathrm{P}+13$ & 72 & 16.9 & \\
\hline $\mathrm{P}+15$ & 10 & 2.3 & Positive: 39.44 \\
\hline P-1 & 4 & 0.9 & \\
\hline P-2 & 7 & 1.6 & \\
\hline P-3 & 1 & 0.2 & \\
\hline P-4 & 6 & 1.4 & \\
\hline P-5 & 22 & 5.2 & \\
\hline P-6 & 7 & 1.6 & \\
\hline P-7 & 136 & 31.9 & \\
\hline P-8 & 7 & 1.6 & \\
\hline $\mathrm{P}-10$ & 2 & 0.5 & Negative: 45.07 \\
\hline Off8 & 1 & 0.2 & \\
\hline Off10 & 16 & 3.8 & \\
\hline Off12 & 6 & 1.4 & Off record: 5.40 \\
\hline Bald & 43 & 10.1 & Bald: 10.09 \\
\hline Total & 426 & 100 & 100 \\
\hline
\end{tabular}

There is a relatively balanced adoption of positive and negative politeness strategies, with the use of negative politeness strategies $5.63 \%$ higher than that of negative ones.

There is some extent of directness in the way students expressed their criticism. As mentioned in 2.3.2, being deductive is a rhetoric realization of positive politeness strategy. Table 1 shows 8 out of 12 or two thirds of the emails were written in the deductive style. Additionally, when criticizing, students also employed bald critical statements, which make up $10.09 \%$ (see Table 2). They brought out their critical topics quickly and sometimes 
spoke out their criticism directly without using any politeness strategies.

According to the statistics in Table 2, four groups of politeness strategies were further identified in Table 3 as the most often used, accounting for a total of $78.1 \%$ :

Table 3. Three most often used groups of politeness strategies

\begin{tabular}{|c|c|c|c|}
\hline Group & $\begin{array}{l}\text { Total } \\
\text { percentage }\end{array}$ & Politeness strategies & Percentage \\
\hline \multirow[t]{5}{*}{$\begin{array}{l}\text { Seeking } \\
\text { ground }\end{array}$} & \multirow[t]{5}{*}{34} & $\begin{array}{l}\mathrm{P}+2 \text { : Exaggerate (interest, approval, sympathy) } \\
\text { with } \mathrm{H} \text { (hearer) }\end{array}$ & 4.2 \\
\hline & & $\mathrm{P}+4$ : Use in-group identity markers & 3.8 \\
\hline & & $\mathrm{P}+7$ : Presuppose/raise/assert common ground & 6.8 \\
\hline & & $\mathrm{P}+13$ : Give reasons & 16.9 \\
\hline & & $\begin{array}{l}\mathrm{P}+15 \text { : Give gifts to } \mathrm{H} \text { (goods, sympathy, } \\
\text { understanding, cooperation) }\end{array}$ & 2.3 \\
\hline Impersonalizing & 31.9 & P-7: Impersonalize S (speaker) and $\mathrm{H}$ & 31.9 \\
\hline \multirow[t]{2}{*}{ Making apologies } & \multirow[t]{2}{*}{6.8} & P-5: Give deference & 5.2 \\
\hline & & P-6: Apologize & 1.6 \\
\hline \multirow[t]{2}{*}{ Using questions } & \multirow[t]{2}{*}{5.4} & P-2: Questions, hedge & 1.6 \\
\hline & & OFF 10: Use rhetorical questions & 3.8 \\
\hline Total & 78.1 & & 78.1 \\
\hline
\end{tabular}

When doing criticism, the most often used group of politeness strategies is "seeking common ground". Students realized this aim by using four positive politeness strategies with a total proportion of 34\%: "exaggerate (interest, approval, sympathy) with $\mathrm{H}(\mathrm{P}+2)$ ", $4.2 \%$; "use in-group identity markers $(\mathrm{P}+4)$ ", 3.8\%; "presuppose/raise/assert common ground $(\mathrm{P}+7)$ ", 6.8\%; "give reasons $(\mathrm{P}+13)$ ", 16.9\%; and "give gifts to $\mathrm{H}$ (goods, sympathy, understanding, cooperation) $(\mathrm{P}+15) ", 2.3 \%$.

The second most often used group of politeness strategy is "impersonalizing" with its total use accounting for $31.9 \%$. The discussion of its use will be presented in the next section of 4.3 .

The third most often used group of politeness strategy is "making apologies". After criticizing, the Chinese students often attributed the problems to themselves and made apologies to show their regret and respect. That is why apologies used to show debt $(\mathrm{P}+6)$ and self-attribution used to show deference $(\mathrm{P}-5)$ are most prominent negative politeness strategies with their total percentage of $6.8 \%$. For example:

P-5: Maybe my opinion is too subjective. I can't deny that I am a little sensitive.

P-6: Sorry not to see it in the bright way as you wish.

The fourth most often adopted politeness strategy, which accounts for 5.4\%, is "using questions", either as a negative politeness strategy or as off-mark rhetorical question, to make criticism appear like an inquiry. For instance:

P-2: why do we Chinese have to study English very well?

Off 10: ... but isn't it too much?

In addition, students also use hedges, such as "however" and "but" as a strategy (P-2) to indicate half agreement and half disagreement. For example:

It is very kind of you to teach us how to learn vocabulary; however, I had to tell you that the methods are nearly useless for me.

As aforementioned in 2.3.2, positive strategies are often used by the members with symmetrical power and social distance in the solidarity politeness system or by the "higher" members in the hierarchy politeness system. The roughly equal employment of positive and negative politeness strategies by the critical students indicates a relatively egalitarian teacher-student relationship. As a protagonist of CLT, Simon advocated 
student-centeredness and participated in various after-class activities. He intended to become, in his words, "a teacher friend" of his students.

As explained in 2.2, "mianzi"/face in Chinese culture is a more communal and interpersonal concept and the Chinese concept of face has very little to do with an individual's need for unhindered freedom of action or attention. The high incidence of the use of "seeking common ground" group of politeness strategies indicates that though the students were asserting their independence by uttering criticism, they exercised caution to maintain a harmonious teacher-student relationship. This concurs with their choice of negative politeness strategies: the most popular types are impersonalizing and making apologies. They seemed to feel guilty after criticizing their teacher friend and adopted plural pronouns rather than the singular "I" and "you" in composing criticism.

In summary, the relatively even use of positive and negative politeness strategies indicates that solidarity and equality existed between the students and their western teacher; the students email-talked to their "teacher friend", showing care and empathy while criticizing. With less constraint of face in email communication, they preferred the use of deductive style and sometimes made bald critical statements. It seems that they put a lot of thought in composing their critical messages and their Chinese facework played a positive role, making their direct criticism sound polite and friendly.

\subsection{On Whose Behalf Was the Criticism Intended to Be Read?}

A scrutiny on the most adopted negative politeness strategy "impersonalizing $\mathrm{S}$ and $\mathrm{H}$ " may contribute to a better understanding of the identity intended by the students to be read. A noticeable feature of these critical emails is students' use of plural personal pronouns to refer to their own opinions and situations. The total length of 12 Chinese students' emails is 3582 words and 130 such kind of pronouns were used, as is in sharp contrast with Simon's replies, of which the total length is 7492 and only 32 "we" were used. These personal pronouns and their references are summarized in Table 4.

Table 4. Marked use of plural personal pronouns

\begin{tabular}{|c|c|c|c|}
\hline Pronouns & Type & References & Examples \\
\hline \multirow{6}{*}{$\begin{array}{l}\text { We } \\
\text { (our, us) }\end{array}$} & we 1 & classmates and I & We couldn't help laughing, so the class was a little noisy. \\
\hline & we 2 & faculty students & $\begin{array}{l}\text { I am the chief editor of our faculty's magazine. ... I have } \\
\text { collected six questions among the students ... will we get a } \\
\text { text book in the future? }\end{array}$ \\
\hline & we 3 & $\begin{array}{l}\text { the students in the } \\
\text { university }\end{array}$ & Do you think we have too many English classes? \\
\hline & we 4 & Chinese students & Why do we Chinese have to study English very well? \\
\hline & we 5 & language learners & $\begin{array}{l}\text { When we study a new language, we need to listen first and } \\
\text { then do imitation. }\end{array}$ \\
\hline & we 6 & you and I as teachers & $\begin{array}{l}\text { In my view, we teachers should show our opinions after } \\
\text { students finish their speech if we don't agree with them. }\end{array}$ \\
\hline $\begin{array}{l}\text { You } \\
\text { (your) }\end{array}$ & you 1 & you and I as teachers & $\begin{array}{l}\text { You won't be considered as a good teacher, so you may be } \\
\text { under pressure. }\end{array}$ \\
\hline \multirow{4}{*}{$\begin{array}{l}\text { They } \\
\text { (their, } \\
\text { them) }\end{array}$} & they 1 & classmates & I heard something from my classmates. They said ... \\
\hline & they 2 & $\begin{array}{l}\text { students of a } \\
\text { particular kind }\end{array}$ & $\begin{array}{l}\text { Teachers think they are too proud. ...Why not try to change } \\
\text { them instead of criticizing them? }\end{array}$ \\
\hline & they 3 & $\begin{array}{l}\text { teachers in Chinese } \\
\text { middle schools }\end{array}$ & $\begin{array}{l}\text { If they spend more time playing games or some other } \\
\text { activities rather than teaching the knowledge in the textbook, } \\
\text { they won't be considered as good teachers. }\end{array}$ \\
\hline & they 4 & $\begin{array}{l}\text { students in Chinese } \\
\text { schools }\end{array}$ & If they don't do it, they won't pass exams. \\
\hline
\end{tabular}


Researchers on contrastive rhetoric of Chinese and English writing attribute the frequent use of collective personal pronouns in Chinese students' English writing to culture transfer, i.e. their writing is influenced by Chinese collectivism (Trandis, 1995; Hinkel, 1999). Chinese student writers often create a "collectivized voice" by mixing themselves with others and effacing their individual identity (Ouyang \& Tang, 2006). The evidence from this study is consistent with this view. Students adopted numerous plural personal pronouns in email writing, creating a collective impression and collectivizing the criticism.

A second consideration is that the use of plural personal pronouns was motivated by face concern. Brown and Levison (1987) interpreted the avoidance of the pronouns "I" and "you" as "conventional indirectness" (p.199) and the person switches as a "strategic point-of-view operation" (p. 202) with which the speaker can afford the distancing to the hearer as if one of them were not present. Since the students under this study were making criticism, a serious face-threatening act, especially in Chinese culture where face and harmony are prioritized, they tried to rescue the recipient's face by directing their implied criticism to a seemingly irrelevant third party marked by "they". They attempted to protect their own face and avoid direct confrontations by blurring their critical stance, as marked by the use of "we". They tried to establish in-group bond and create the feeling of "being in the same boat" by involving the recipient, as marked by the use of "you". The frequent switches between "we", "you", "they" and "I" required the recipient, the western teacher Simon, to constantly change his viewpoint, associating or disassociating with the critic, and thus blunted the sharpness of the criticism.

However, besides these cultural and pragmatic considerations, a question not answered yet is: In this particular community, did the use of these plural personal pronouns make these students' voice stronger or weaker, more effective or ineffective?

In order to answer this question, the first thing that needs to be known is whether the problems mentioned in these critical emails were the ones of many other students or just the writers' individual opinions. Based upon the reflective essays written by the students at the end of the semester and my interviews with them, I found that an estimate of $80 \%$ of students commented on this program in a half-half manner, i.e. they appreciated the new ways of learning exhibited in the program but doubted its applicability in their future teaching. Therefore, communicating criticism in a collective voice is not merely a politeness strategy or cultural phenomenon. The criticism did, to a large extent, represent a majority's opinions. A careful look at Table 4 may explicate that, generally speaking, students borrowed "we", "you" and "they" to utter their own voices and to realize their three "I" identities:

a) Past "I" as a student in a Chinese middle school: "they4";

b) Present "I" as one of the students learning English in universities: "we1", "we2", "we3", "we4", "we5", "they1" and "they2";

c) Future "I" as a teacher in a Chinese middle school: "we6", "you1" and "they3".

What could be deduced is that students' criticism of the teacher or the program was based upon their overall considerations of their past and present learning situations and pessimistic predictions of future teaching environment. They expressed doubts and disapproval as going-to-be Chinese teachers, the student members of this particular CLT-based community and individual students who suffered from the dilemma of wishing to be modern but having to do traditional English teaching in reality. As to their teacher, when answering students' emails, Simon often used "you and your classmates", as indicated that he interpreted the criticism not as individual but collective. It was his usual practice to begin his class with a discussion of the problems mentioned in students' emails.

As noted in Introduction, email as a communication medium features little social presence; and as a form of language, email allows both informality and formality. By using emails, students' real faces were invisible and, without strict grammatical requirements, they could freely create other faces by using various pronouns to talk for them. The face magic played by email communication made email a crucial channel for Simon to perceive problems in the program. As he wrote in one reply:

Thank you for your comments about the class. I am finding that email is a good way to receive feedbacks from my students after each lecture as the big class makes it difficult for "small talks".

Therefore, in this particular community, the collectivized email voice uttered by critical students helped students express their concerns more loudly and safely.

In summary, there is a culture of being collectivistic; there is truth in being collective; and there is face saved by being collective. The switches between personal pronouns, though creating vagueness, could also be interpreted as a politeness gesture which gave these students another persona to utter disapprovals. Due to the fact that the 
problems reported in these critical emails were not individual ones but students' common concerns, the collective voices adopted in them raised the attention of the western teacher who took the criticism seriously and tried to fix the problems in time.

\section{Conclusions}

This paper has examined the role of email in communicating criticism between Chinese students and their western teacher in an English curriculum reform context. It has revealed that email is an effective means to communicate pedagogical differences between students and teachers from different cultures with distinct interpersonal communication habits and differing ideologies of English teaching and learning. The study is situated in the contemporary Chinese context featuring the coexistence of increasing pedagogical and technological modernization (such as CLT-centered English curriculum reform and email communication) and traditional culture and practices of, for instance, facework. With the "sociocultural turn" (Johnson, 2006) in second language teaching and education research and given a limited body of literature on face in intercultural settings (Wang \& Spenser-Oatey, 2015), the present study contributes to English language teaching research and face research by evidencing the three roles of email in communicating criticism in an intercultural English teaching and learning context: first, email functioned as a safe, polite and effective channel for Chinese students to express critical views directly (without turning to the third party) and collectively (on behalf of the other students); second, email worked as a major means for their western teacher to be informed problems privately; third, email acted as a springboard for the western teacher to communicate later with more students publicly. In the process of negotiating differences and communicating criticism, what has not changed much is the time-honored face tactics; what has changed is the context where the face tactics take place.

Besides, the study confirms the general view that people tend to behave differently in computer-mediated and face-to-face communication contexts (Okdie et al., 2011); the computer-mediated realm may buffer the negative feelings in communicating unpleasant topics (Lewandowski et al., 2011); and despite the disparities between the virtual and face-to-face communication, the socioculturally dependent communication rules and social psychology can be played out similarly by computer-mediated technologies (Ou, Pavlou, \& Davison, 2014). Adopting a sociocultural perspective, it enriches the existing research on email communication by scrutinizing and highlighting its effect on social relations which are often neglected by previous research (Vinagre, 2008).

It is hoped that larger scale studies will be conducted in the future to explore the potential of using email and other computer-mediated modes to improve intercultural communication, enhance mutual understandings and increase success in English language teaching reforms.

\section{Acknowledgements}

The research was supported by Research Projects on Humanities and Social Sciences for Innovation and Enhancement of Colleges and Universities in Guangdong Province, China (Project Code: 15Q2 ).

\section{References}

Alharbi, M. (2015). Effects of blackboard's discussion boards, blogs and wikis on effective integration and development of literacy skills in EFL Students. English Language Teaching, 8(6), 111-132. https://doi.org/10.5539/elt.v8n6p111

Baron, N. (1998). Letters by phone or speech by any other means: The linguistics of email. Language and Communication, 18, 133-170. https://doi.org/10.1016/S0271-5309(98)00005-6

Barson, J., Frommer, J., \& Schwartz, M. (1993). Foreign language learning using e-mail in a task-oriented perspective: Interuniversity experiments in communication and collaboration. Journal of Science Education and Technology, 2(2), 565-584. https://doi.org/10.1007/BF00695325

Bloch, J. (2002). Student/teacher interaction via email: the social context of Internet discourse. Journal of Second Language Writing, 11, 117-134. https://doi.org/10.1016/S1060-3743(02)00064-4

Brown, P. \& Levinson, S. 1987. Politeness: Some universals in language usage (2nd Ed.). Cambridge: Cambridge University Press (Originally published as 'Universals in language usage: Politeness phenomena'. In Goody, E., 1978. Questions and Politeness: Strategies in Social Interaction).

Cortazzi, M., \& Jin, L. (1996). English teaching and learning in China. Language Teaching, (4), 61-80. https://doi.org/10.1017/S0261444800008351

Cutler, R. H. (1996). Technologies, relations and selves. In L. Strate, R. Jacobson, \& S. B. Gibson (Eds.), Communication and cyberspace: Social interaction in an electronic environment (pp. 317-333). Cresskill, NJ: Hampton Press. 
Dzau, Y. Z. (Ed.). (1990). English in China. Hong Kong: API Press.

Gao, G., Ting-Toomey, S., \& Gudykunst, W. (1996). Chinese communication process. In M. Bond (Ed.), Handbook of Chinese psychology (pp. 280-293). Hong Kong: Oxford University Press.

Goffman, E. (1967). Interaction ritual. New York: Doubleday Anchor.

Grice, H. P. (1978). Further notes on logic and conversation. In Cole, P. (Ed.) Syntax and Semantics, 9 (pp. 113-127). New York: Academic Press.

Grice, H. P. (1975). Logic and conversation. In P. Cole, \& J. Morgan (Eds.). Syntax and semantics, 3 (pp. 41-58). New York: Academic Press.

Hayhoe, R. (1996). China's universities 1895-1995: A century of cultural conflicts. New York: Grune \& Stratton. https://doi.org/10.4324/9780203344804

Hinkel, E. (1999). Objectivity and credibility in L1 and L2 academic writing. In E. Hinkel (Ed.) Culture in second language teaching and learning. Cambridge, UK: Cambridge University Press.

Hofstede, G. (2008). Consequences of culture: Comparing values, behaviors, institutions and organizations across nations (2nd Ed.). Shanghai: Shanghai Foreign Language Education Press.

Hu. C., W. A., Cheah, H., \& Wong, P. (2009). Patterns of email use by teachers and implications: A Singapore experience. Computer \& Education, 53(3), 623-631. https://doi.org/10.1016/j.compedu.2009.04.007

$\mathrm{Hu}, \mathrm{H}$. C. (1944). The Chinese concept of 'face'. American Anthropologist, 46, 45-46. https://doi.org/10.1525/aa.1944.46.1.02a00040

Hu, W. Z., \& Grove, C. (1991). Encountering the Chinese: A guide for Americans. Yarmouth, Maine: Intercultural Press.

Johnson, K. E. (2006). The sociocultural turn and its challenges for second language teacher education. TESOL Quarterly, 40(1), 235-237. https://doi.org/10.2307/40264518

Lewandowski, J., Rosenberg, B. D., Parks, M. J., \& Siegel, J. T. (2011). The effect of informal social support: Face-to-face versus computer-mediated communication. Computers in Human Behavior, 27, 1806-1814. https://doi.org/10.1016/j.chb.2011.03.008

Lewis, D. C., Treves, M. D., \& Shaindlin, A. B. (1997). Making sense of academic cyberspace: Case study of an electronic classroom. College Teaching, 45, 96-100. https://doi.org/10.1080/87567559709596203

Lightfoot, M. J. (2006). A comparative analysis of e-mail and face-to-face communication in an educational environment. Internet and Higher Education, 9, 217-227. https://doi.org/10.1016/j.iheduc.2006.06.002

Lo, B. L. (1984). Teacher education in the eighties. In R. Hayhoe (Ed.), Contemporary Chinese education (pp. 3-20). Armonk, NY: M. E. Sharpe.

Mao, L. M. R. (1994). Beyond politeness theory: "Face" revisited and renewed. Journal of Pragmatics, 1/5, 451-486. https://doi.org/10.1016/0378-2166(94)90025-6

Oatey, H. (1990). Teacher training in the PRC: Influence of Sociocultural factors. In Y. F. Dzau (Ed.), English in China (pp. 250-263). Hong Kong: API Press.

O'Driscoll, J. (1996). About face: a defense and elaboration of universal dualism. Journal of Pragmatics 25(1), 1-32. https://doi.org/10.1016/0378-2166(94)00069-X

Okdie, B., Guadagno, R., Bernieri, F., Geers, A., \& Mclarney-Vesotski, A. (2011). Getting to know you: Face-to-face versus online interactions. Computer in Human Behavior, 27, 153-159. https://doi.org/10.1016/j.chb.2010.07.017

Ou, C. X., Pavlou, P. A., \& Davison, R. M. (2014). Swift guanxi in online marketplaces: The role of computer-mediated communication technologies. MIS Quarterly, 38(1), 209-230. https://doi.org/10.25300/MISQ/2014/38.1.10

Ouyang, H. H. (2004). Remaking of face and community of practices: An ethnography of local and expatriate English teachers reform stories in today's China. Beijing: Peking University Press.

Ouyang, H. H., \& Tang, S. Y. (2006). Writer identity in Chinese college students' L2 argumentative writing. Journal of PLA University of Foreign Languages, 29(2), 49-53. (In Chinese)

Scollon, R., \& Scollon, S. (1995). Intercultural communication: A discourse approach. Cambridge: Blackwell. 
Simpson, T. S. (2008). Western EFL teachers and east-west classroom-culture conflicts. Regional Language Center Journal, 39(3), 381-294. https://doi.org/10.1177/0033688208096847

$\mathrm{Su}, \mathrm{X}$. (1998). Chinese examinations in historical perspective. In K. Parry, \& X. Su (Eds.), Culture, literacy, and learning English: Voices from the Chinese classroom (pp. 37-39). Portsmouth, NH: Boynton/Cook.

Spolsky, B. (1997). The ethics of gatekeeping tests: What have we learned in a hundred years. Language Testing, 14(3), 242-47. https://doi.org/10.1177/026553229701400302

Triandis, H. C. (1995). Individualism and collectivism. Boulder, CO: Westview.

Tsui, A. (2007). Complexities of identity formation: A narrative enquiry of an EFL teacher. TESOL Quarterly, 41(4), 657-680. https://doi.org/10.1002/j.1545-7249.2007.tb00098.x

Turkle, S. (1995). Life on the screen: Identity in the age of the Internet. New York: Simon \& Shuster.

Vinagre, M. (2008). Politeness strategies in collaborative e-mail exchanges. Computers and Education, 50, 1022-1036. https://doi.org/10.1016/j.compedu.2006.10.002

Wang, J., \& Spencer-Oatey, H. (2015). The gains and losses of face in ongoing intercultural interaction: A case study of Chinese participant perspectives. Journal of Pragmatics, 89, 50-65. https://doi.org/10.1016/j.pragma.2015.09.007

Yu, L., \& Zeng, G. (2011). Managing CMC-based task through text-based dialogue: An exploratory study in a Chinese EFL context. English Language Teaching, 4(4), 221-233. https://doi.org/10.5539/elt.v4n4p221

Yu, M. C. (1997). Interlanguage pragmatics: cross-cultural investigation of the requestive behavior of Chinese learners of English (Unpublished doctoral thesis). Harvard University, Cambridge.

$\mathrm{Yu}$, M. C. (1999). Universalistic and culture-specific perspectives on variation in the acquisition of pragmatic competence in a second language. Pragmatics, 9(2), 281-312. https://doi.org/10.1075/prag.9.2.04yu

Yu. M. C. (2003). On the university of face: Evidence from Chinese compliment response behavior. Journal of Pragmatics, 35, 1670-1710. https://doi.org/10.1016/S0378-2166(03)00074-2

Zhang, N. (2005). Transfer of mental spaces by means of pronouns and principles of politeness. Journal of Hunan First Normal College, 5(4), 92-95. (In Chinese)

Zhang, Y. (1995). Indirectness in Chinese requesting. In G. Kasper (Ed.), Pragmatics of Chinese as native and target language (pp. 69-118). Honolulu, HI: University of Hawai'i Press.

\section{Notes}

Note 1. Redressive action means the action that gives face to the other and counteracts the potential face damage of the FTA (Brown \& Levinson, 1987: 69).

Note 2. For confidentiality reasons, all the names, personal and institutional, are pseudonyms.

Noe 3. A list with all politeness strategies and their codes is included in Appendix.

Note 4. The author corrected the major grammatical mistakes in the cited email to avoid misunderstandings and, for the sake of authenticity, kept the minor ones which would not affect readers' rendering of meaning.

Note 5. "The exam" refers to "college entrance examination" in China which is often considered as the most important examination determining a student's fate or future prosperity.

Note 6. TEM, short for Test for English Majors, is an English proficiency test organized by Chinese Ministry of Education for English majors.

Note 7. Since 2004, oral English has been included in China's college entrance examination, TEM 4 and TEM 8 in some developed regions like Guangdong. 


\section{Appendix}

Tables 5-8: Politeness strategies and their codes (cf. Vinagre, 2008: 1034-1035)

Table 5. Politeness, bald on record

\begin{tabular}{ll}
\hline Strategy & Description \\
\hline Bald on record (ON) & As speaking in conformity with Grice's Maxims (Grice, 1975) \\
Maxim of quality & Be non-spurious (speak the truth, be sincere) \\
Maxim of quantity & Do not say less than is required; do not say more that is required \\
Maxim of relevance & Be relevant \\
Maxim of manner & Be perspicuous; avoid ambiguity and obscurity \\
\hline
\end{tabular}

Adapted from Grice (1975).

Table 6. Strategies of positive politeness

\begin{tabular}{|c|c|}
\hline Strategy & Example \\
\hline $\begin{array}{l}(\mathrm{P}+1) \text { : Notice, attend to } \mathrm{H} \text { (his interest, wants, needs } \\
\text { goods) }\end{array}$ & Your skirt is lovely, where did you get it? \\
\hline$(\mathrm{P}+2)$ : Exaggerate (interest, approval, sympathy with $\mathrm{H})$ & How absolutely extraordinary! \\
\hline$(\mathrm{P}+3)$ : Intensify interest to $\mathrm{H}$ & You always do the dishes! I will do them tonight \\
\hline$(\mathrm{P}+4):$ Use in group identity markers & Hello mate, long time no see! \\
\hline$(P+5):$ Seek agreement & $\begin{array}{l}\text { How about the match last night? Did Real Madrid } \\
\text { play well or what! }\end{array}$ \\
\hline$(P+6):$ Avoid disagreement & I will meet you at eleven, then \\
\hline$(\mathrm{P}+7):$ Presuppose/raise/assert common ground & Oh, this is lovely! (walking into a house) \\
\hline$(\mathrm{P}+8):$ Joke & $\begin{array}{l}\text { How about lending me those crystals } \\
\text { (diamonds)? }\end{array}$ \\
\hline $\begin{array}{l}(P+9): \text { Assert or presuppose S's knowledge of and } \\
\text { concern for H's wants }\end{array}$ & $\begin{array}{l}\text { I know you wanted the last book by Paxman but } \\
\text { they didn't have it so I got you this one instead }\end{array}$ \\
\hline$(\mathrm{P}+10):$ Offer, promise & I will send you those documents next week! \\
\hline$(\mathrm{P}+11):$ Be optimistic & I will talk to you soon \\
\hline$(P+12):$ Include both $\mathrm{S}$ and $\mathrm{H}$ in the activity & We are a bit tired, aren't we? \\
\hline$(\mathrm{P}+13):$ Give (or ask for) reasons & I am really late for the interview, so. . \\
\hline$(P+14):$ Assume or assert reciprocity & $\begin{array}{l}\text { I will help you with your Spanish I hope you can } \\
\text { do the same with my English }\end{array}$ \\
\hline $\begin{array}{l}(\mathrm{P}+15) \text { : Give gifts to } \mathrm{H} \text { (goods, sympathy, understanding, } \\
\text { cooperation) }\end{array}$ & I hope you are not too stressed with your exams \\
\hline
\end{tabular}

Adapted from Brown and Levinson (1978). 
Table 7. Strategies of negative politeness

\begin{tabular}{ll}
\hline Strategy & Example \\
\hline$(\mathrm{P}-1):$ Be conventionally indirect & Can you please tell me the time? \\
$(\mathrm{P}-2):$ Questions, hedge & This may not be relevant but. . \\
$(\mathrm{P}-3):$ Be pessimistic & Could you set the table? \\
$(\mathrm{P}-4):$ Minimize the imposition & I just dropped by for a minute to ask you... \\
$(\mathrm{P}-5):$ Give deference & Excuse me, sir, would you mind if I close the \\
& window? \\
$(\mathrm{P}-6):$ Apologize & I do not want to bother you, but... \\
$(\mathrm{P}-7):$ Impersonalize $\mathrm{S}$ and $\mathrm{H}$ & Is it possible to ask a favor? \\
$(\mathrm{P}-8):$ State the FTA as a general rule & We do not eat with our hands, we eat with knives \\
& and forks \\
$(\mathrm{P}-9):$ Nominalize & We urgently require your help \\
$(\mathrm{P}-10):$ Go on record as incurring a debt, or as not & I'd really appreciate it if you would... \\
indebting H & \\
\hline
\end{tabular}

Adapted from Brown and Levinson (1978).

Table 8. Off record

\begin{tabular}{|c|c|}
\hline Strategy & Example \\
\hline (OFF 1): Give hints & It is warm in here (open the window) \\
\hline (OFF 2): Give association clues & I have to work late again (wash the dishes) \\
\hline (OFF 3): Presuppose & I got up again last night (may imply criticism) \\
\hline (OFF 4): Understate & What did you think of the food? It's not half bad \\
\hline (OFF 5): Overstate & $\begin{array}{l}\text { Everybody was out shopping today! (that's why I } \\
\text { am late) }\end{array}$ \\
\hline (OFF 6): Use tautologies & $\begin{array}{l}\text { A man's got to do what a man's got to do (used } \\
\text { as an excuse) }\end{array}$ \\
\hline (OFF 7): Use contradictions & $\begin{array}{l}\text { Can you help with this? Well, I can and I can't } \\
\text { (may imply criticism) }\end{array}$ \\
\hline (OFF 8): Be ironic & $\begin{array}{l}\text { This is great weather we're having (while } \\
\text { pouring down outside) }\end{array}$ \\
\hline (OFF 9): Use metaphors & He is a real fish (i.e. He drinks like a fish) \\
\hline (OFF 10): Use rhetorical questions & $\begin{array}{l}\text { How many times do I have to tell you ...? } \\
\text { (criticism) }\end{array}$ \\
\hline (OFF 11): Be ambiguous & Peter's pretty smooth (compliment or insult) \\
\hline (OFF 12): Be vague & I think someone has been naughty (criticism) \\
\hline (OFF 13): Over-generalize & Dinner has to be cooked \\
\hline (OFF 14): Displace H & $\begin{array}{l}\text { Diana, could you pass me the newspaper? } \\
\text { (hoping that Peter who's nearer will do it } \\
\text { himself) }\end{array}$ \\
\hline (OFF 15): Be incomplete, use ellipsis & Well, if you leave your things around... \\
\hline
\end{tabular}

Adapted from Brown and Levinson (1978).

\section{Copyrights}

Copyright for this article is retained by the author(s), with first publication rights granted to the journal.

This is an open-access article distributed under the terms and conditions of the Creative Commons Attribution license (http://creativecommons.org/licenses/by/4.0/). 